\title{
Modernizacja i budowa czystego taboru transportu publicznego na terenie miast i w obszarach metropolitalnych - tabor trolejbusowy
}

\author{
(Materiat do artykutu przedstawiono w formie prezentacji na Międzynarodowych \\ Targach Poznańskich - Transporta 2009 - Transport Szynowy XXI wieku dla Polski)
}

\section{Wstęp}

Pojazdy trakcji elektrycznej są znaczącym odbiorcą energii elektrycznej.

Moc napędów zainstalowanych: w lokomotywach osiaga $6 \mathrm{MW}$, w pociaggach metra $3 \mathrm{MW}$ w tramwajach $600 \div 800 \mathrm{~kW}$.

Współczesne tranzystorowe układy regulacyjne umożliwiają wykorzystanie pobieranej z podstacji energii ze stosunkowo wysoką sprawnością 0.9 . Układy te umożliwiają również częściowe odzyskanie energii kinetycznej rozpędzonego pojazdu podczas hamowania. Dotyczy to zwłaszcza pojazdów zasilanych z sieci trakcyjnej prądu stałego (takich jak tramwaje, trolejbusy, metro) oraz pojazdy kolejowe w krajach z systemem zasilania 3000 V DC i 1500 V DC.

Teoretycznie w trakcji miejskiej można odzyskać $20 \div 40 \%$ pobranej na rozruch i jazdę energii zależnie od gęstości ruchu, prędkości komunikacyjnej oraz struktury układu zasilania sieci trakcyjnej. Można więc odzyskać ok. $40 \mathrm{MWh}$ rocznie na jeden tramwaj, czyli dla miasta średniej wielkości eksploatującego 400 tramwajów, roczna oszczędność energii wynosi ok. $16000 \mathrm{MWh}$. Dla trakcji kolejowej przy dużych odległościach zwracaną energię można oszacować na kilka procent. Stosowanie rekuperacyjnego hamowania jest więc uzasadnione tylko $\mathrm{w}$ ruchu podmiejskim $\mathrm{i}$ w terenach górzystych.

Aby rekuperacja była efektywna niezbędna jest możliwość odbioru zwracanej energii przez inne pojazdy znajdujące się $\mathrm{w}$ tym czasie na danym odcin$\mathrm{ku}$ zasilania. Na przykład w Warszawie przy $20 \%$ tramwajów wyposażonych w układ umożliwiający hamowanie rekuperacyjne efektywny zwrot energii nie przekracza $25 \%$ energii pobranej na jazdę. Przy większym udziale taboru z rekuperacją możliwość jej odzysku będzie jeszcze niższa.

Zwiększenie efektywności odzysku energii hamowania pojazdów można osiagnąć poprzez zastosowanie zasobników energii:

- zainstalowanych na podstacjach trakcyjnych, takie rozwiazzanie zastosowano próbnie w kilku miastach,
- zabudowanych na pojeździe umożliwiających przejęcie jego energii hamowania $\mathrm{Z}$ prędkości odpowiadającej warunkom ruchowym. Taki układ z kondensatorowym zasobnikiem energii został zaprojektowany, wykonany i przebadany w Instytucie Elektrotechniki oraz trolejbusach i zgłoszony do Urzędu Patentowego.

Niniejsze opracowanie zawiera podstawowe wyniki z tych badań.

\section{Uklad trolejbusu z kondensatorowym zasobni-} kiem energii

W ubiegłym, 2008 roku Zakład Trakcji Elektrycznej Instytutu Elektrotechniki zaprojektował i wykonał układ kondensatorowego zasobnika energii do trolejbusu eksploatowanego w Kownie na Litwie. System ten został dobudowany do istniejącego układu napędowego z silnikiem prądu stałego, napędzanego z przekształtnika tranzystorowego DC/DC i wyposażony w terminal, wyświetlający niezbędne prądy, napięcia i energię. Uproszczony schemat blokowy tego rozwiązania przedstawiony jest na rysunku poniżej.

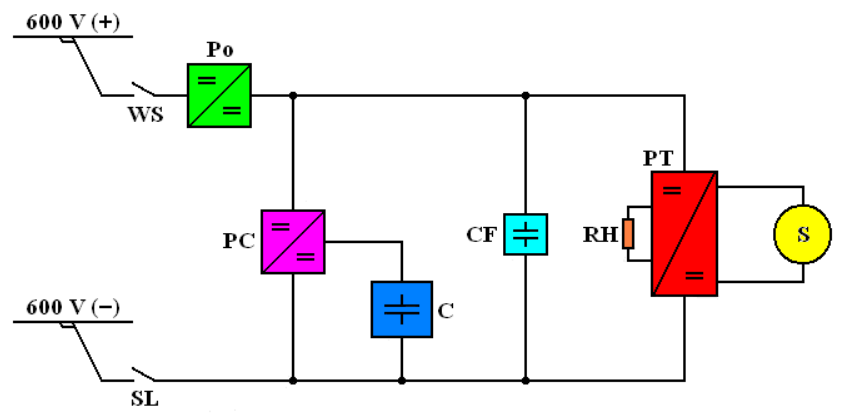

Rys. 1. Schemat blokowy obwodu głównego trolejbusu z kondensatorowym zasobnikiem energii.

Oznaczenia

WS - wyłacznik szybki nadmiarowy

SL - stycznik liniowy

PC - przeksztattnik tadowania kondensatora

$C$ - moduty kondensatorowego zasobnika energii

CF - kondensator filtru sieciowego 


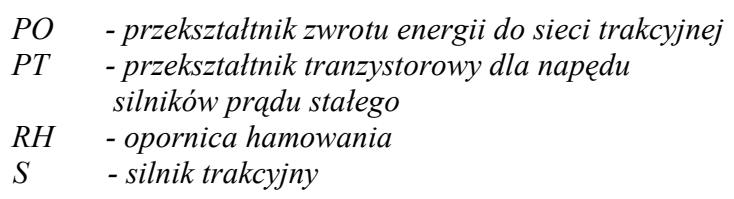

Kondensatorowy zasobnik energii może być stosowany zarówno dla napędu z silnikami prądu stałego jak i dla silników asynchronicznych z falownikiem.

Zasobnik kondensatorowy C ładowany jest podczas hamowania pojazdu przez przekształtnik tranzystora PC kontrolujący prąd ładowania i napięcie kondensatorów. W czasie hamowania energia akumulowana jest $\mathrm{w}$ kondensatorach do momentu osiagnięcia maksymalnych wartości napięcia kondensatorów ok. $750 \mathrm{~V}$. Jeżeli prędkość pojazdu w momencie rozpoczęcia hamowania była większa niż $50 \mathrm{~km} / \mathrm{h}$, a co za tym idzie energia do odzyskania jest wyższa od możliwości zasobnika nadmiar energii odebrany może być przez sieć trakcyjną (przekształtnik PO), jeśli są ku temu możliwości lub tracony w opornicach hamowania. Testy przeprowadzone przy normalnej eksploatacji z pasażerami na różnych liniach wykazały, że praktycznie cała energia hamowania trolejbusu była magazynowana w kondensatorach.

$\mathrm{W}$ czasie rozruchu pojazdu prąd pobierany $\mathrm{z}$ sieci, wspomagany jest $\mathrm{z}$ kondensatorami aż do momentu obniżenia jego napięcia do wartości minimalnej. Poniższe oscylogramy przedstawiają odpowiednio prądy i napięcia dla przypadku bez zasobnika energii (Osc. 1) oraz z układem zasobnika energii przy jeździe na sieci (Osc.2 i 3 ).

Jak widać w przypadku przejazdu na sieci bez zasobnika kondensatorowego, prąd sieci podczas rozruchu narasta liniowo do wartości ok. 350A, a następnie jest przejście na charakterystykę, podczas hamowania, cała energia tracona jest $\mathrm{w}$ opornikach hamowania.

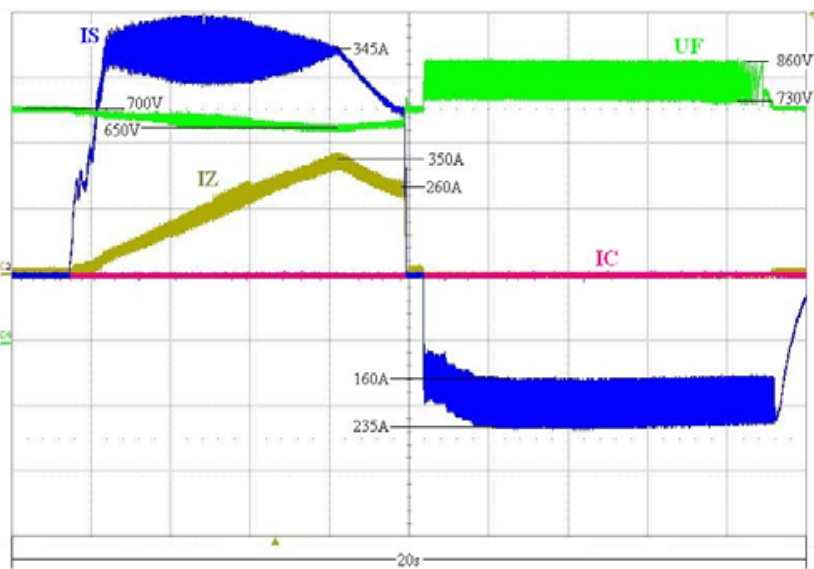

Osc. 1. Przejazd trolejbusu na sieci trakcyjnej bez zasobnika Legenda: kondensatorowego

IS - prad silnika;

IC - prad zasobnika kondensa torowego,

$I Z$ - prad sieci;

$U F$ - napięcie kondensatora filtru.

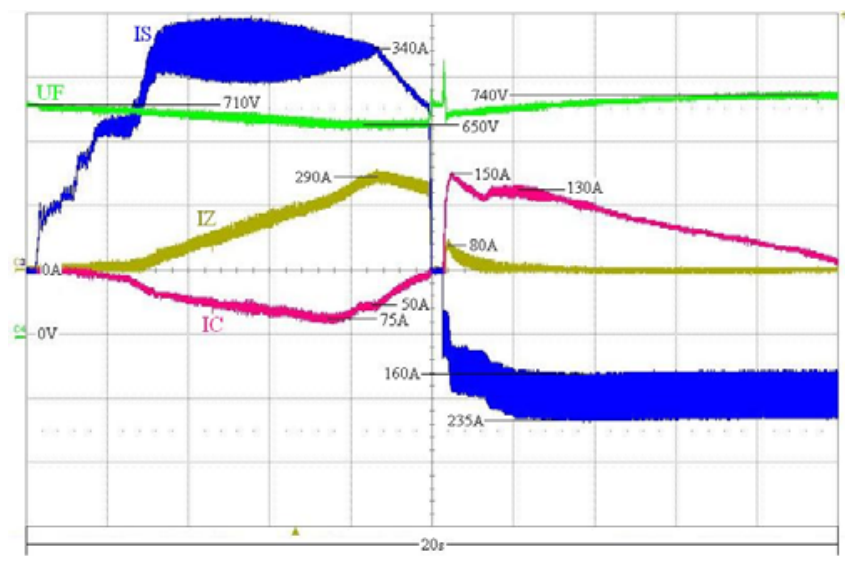

Osc. 2. Przejazd trolejbusu na sieci trakcyjnej wspomaganej zasobnikiem kondensatorowym (równe napięcia początkowe sieci i kondensatora)

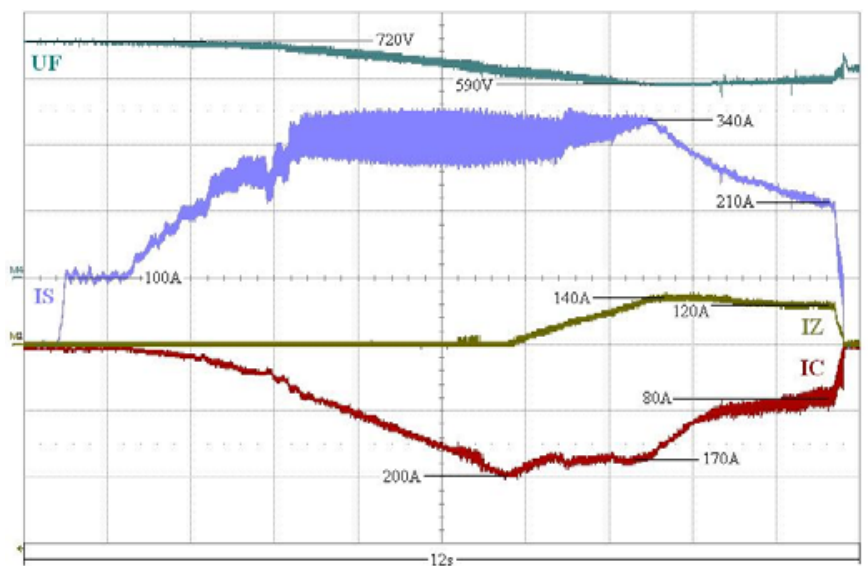

Osc. 3. Przejazd trolejbusu na sieci trakcyjnej wspomaganej zasobnikiem kondensatorowym (napięcia początkowe kondensatora wyższe od napięcia sieci)

Legenda:

IS - prad silnika;
IC-prad zasobnika kondensatorowego;
IZ-prqd sieci;
UF - napięcie kondensatora filtru.

Oscylogram 2 przedstawia przejazd odcinka na sieci, wspomaganej kondensatorowym zasobnikiem energii. Jak widać przebieg prądu pobranego z sieci trakcyjnej podczas rozruchu jest bardziej łagodny, w porównaniu z pierwszym przypadkiem, a wartość maksymalna IŻ wynosi ok. 290A. Maksymalna wartość prądu pobranego $\mathrm{z}$ kondensatorów przy rozruchu w tym przypadku to ok. 75A. Dzięki zasobnikowi kondensatorowemu możemy więc zmniejszyć wartość maksymalną prądu pobieranego z podstacji trakcyjnej, a co za tym idzie mniej przeciążamy sieć i zmniejszamy zużycie energii.

Oscylogram 3 przedstawia sam rozruch, również w sytuacji zasilania hybrydowego (sieć + zasobnik). W tym przypadku jednak napięcie na zasobniku jest ok. 120V wyższe niż napięcie zasilania trakcyjnego. Maksymalny prąd pobrany $\mathrm{z}$ zasobnika to ok. $200 \mathrm{~A}$, natomiast $\mathrm{z}$ sieci to ok. $140 \mathrm{~A}$ i pojawia się dopiero po ok. 6 s od rozpoczęcia procesu rozruchu. 
Zamontowanie zasobnika na pojeździe trakcyjnym umożliwia również przejazd bez przyłączenia do sieci trakcyjnej. Trolejbus, przy naładowanym zasobniku jest w stanie przejechać dystans kilkuset metrów przy zachowaniu parametrów jezdnych. Odległość uzależniona jest od warunków terenowych i stylu jazdy kierowcy. Poniższy oscylogram (Osc. 4) pokazuje prądy i napięcia podczas przejazdu odcinka bez sieci trakcyjnej.

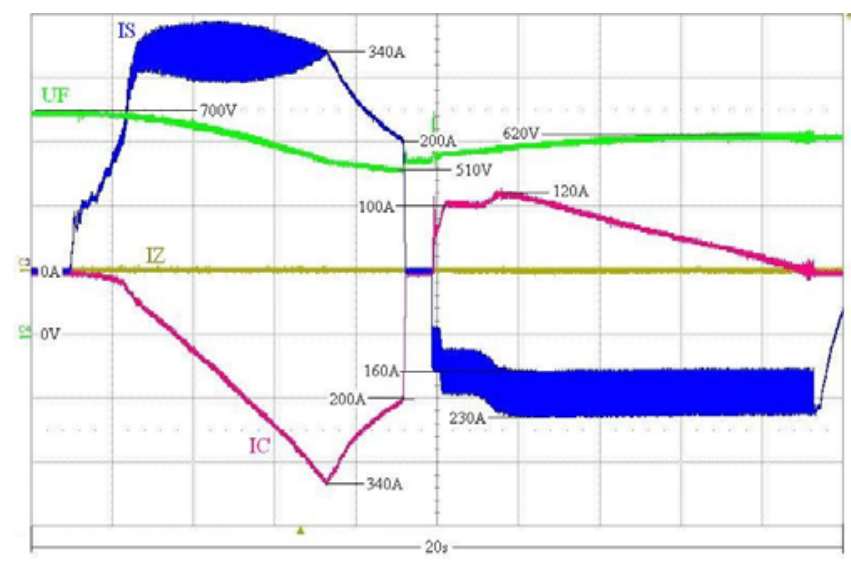

Osc. 4. Przejazd trolejbusu bez sieci trakcyjnej zasilanego z zasobnika kondensatorowego

Legenda:

IS- prad silnika;

IC-prad zasobnika kondensatorowego;

IZ-prad sieci;

UF - napięcie kondensatora filtru.

Kondensator podczas rozruchu prądem do $340 \mathrm{~A}$ rozładowuje się od $700 \mathrm{~V}$ do ok. $510 \mathrm{~V}$, a po hamowaniu osiaga wartość ok. 620V. Napięcie to pozwala na wykonanie ponownego cyklu rozruchu i hamowania, aż do osiągnięcia wartości ok. 400V. Prąd ładowania zasobnika podczas hamowania narasta do ok. 120A.

Wyniki badań uzyskane podczas normalnej eksploatacji trolejbusu z pasażerami potwierdziły, że oszczędność energii $\mathrm{w}$ przypadku zastosowania zasobnika kondensatorowego wzrasta do ok. 30 do $35 \%$, w zależności od stylu jazdy (używanie hamulców mechanicznych, dynamiki jazdy), warunków terenowych (długie zjazdy powodują maksymalne naładowanie zasobnika), a także od używania zwrotnic prądowych, starego typu (prąd potrzebny do przestawienia zwrotnicy wymuszany jest $\mathrm{z}$ sieci trakcyjnej przez opornik hamowania). Wszystkie te czynniki mają bezpośredni wpływ na oszczędność energii w trolejbusie.

\section{Układ trolejbusu z kondensatorowym i akumu- latorowym zasobnikiem energii}

W roku 2006 Instytut Elektrotechniki opracował i wykonał falownikowy układ napędowy dla trolejbusu o mocy $180 \mathrm{~kW}$, wyposażony w kondensatorowy zasobnik energii $0,7 \mathrm{kWh} / 750 \mathrm{~V}$ oraz baterię akumulatorów o energii $7 \mathrm{kWh}$ wraz z dodatkowymi przekształtnikami regulującymi ładowanie i obciążenie zasobników. Celem tego projektu było przejechanie odcinka bez zasilania z sieci trakcyjnej o długości ok. $1200 \mathrm{~m}$.

Dostarczone wyposażenie zostało zamontowane przez MPK Lublin w trolejbusie modelowym. Trolejbus z zasobnikowym układem zasilania został zbadany wspólnie przez MPK Lublin i Instytut Elektrotechniki w czerwcu i lipcu 2007 r. w normalnych warunkach ruchowych.

Obwód blokowy tego rozwiązania przedstawia poniższy rysunek (Rys. 2).

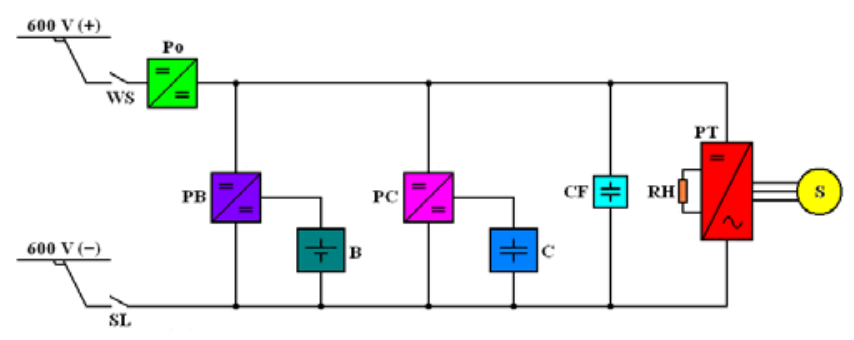

Rys. 2. Schemat blokowy obwodu głównego trolejbusu z kondensatorowym i akumulatorowym zasobnikiem energii.

$$
\begin{aligned}
& \text { Oznaczenia: } \\
& \text { WS - wytacznik szybki nadmiarowy } \\
& \text { SL - stycznik liniowy } \\
& \text { PC - przeksztaltnik tadowania zasobnika } \\
& \quad \text { kondensatorowego } \\
& \text { C - moduly kondensatorowego zasobnika energii } \\
& \text { PB - przeksztattnik tadowania baterii akumulatorów } \\
& \text { B - bateria akumulatorów } \\
& \text { CF- kondensator filtru sieciowego } \\
& \text { PO- przeksztaltnik zwrotu energii do sieci trakcyjnej } \\
& \text { PT- przeksztaltnik (falownik) tranzystorowy dla napędu } \\
& \text { silnika AC } \\
& \text { RH - opornica hamowania } \\
& \text { S - silnik trakcyjny }
\end{aligned}
$$

Oscylogram 5 przedstawia przejazd odcinka ok. $2000 \mathrm{~m}$ bez sieci. Układ napędowy zasilany jest $\mathrm{z}$ dwóch zasobników: kondensatorowego, który pełni tu funkcję źródła mocy i pokrywa impulsy prądowe podczas rozruchu i pozwala przejać i zmagazynować energię przy hamowaniu pojazdu oraz akumulatorowego, którego zadaniem jest dostarczanie na bieżąco energii potrzebnej na przejechanie żądanego odcinka. Osc. 5 przedstawia przebiegi prądów zasobników oraz napięcie kondensatora, a także prędkość pojazdu. $\mathrm{Na}$ tym odcinku znajdowały się cztery przystanki, a przejazd odbywał się w normalnym ruchu miejskim, średnia prędkość trolejbusu wynosiła ok $15 \mathrm{~km} / \mathrm{h}$. Energia pobrana $\mathrm{z}$ baterii akumulatorów dla przejechania tej trasy wyniosła ok. $3,4 \mathrm{kWh}(\sim 1,7 \mathrm{kWh} / \mathrm{km})$, a energia obwodów pomocniczych, takich jak pompa wspomagania kierownicy, sprężarka i alternator baterii pokładowej to ok. 1,0kWh. W tym przypadku rozładowanie baterii akumulatorów wyniosło ok. $47 \%$, natomiast dla trasy żądanej 1200m 21\%. Dla zachowania dłuższej 


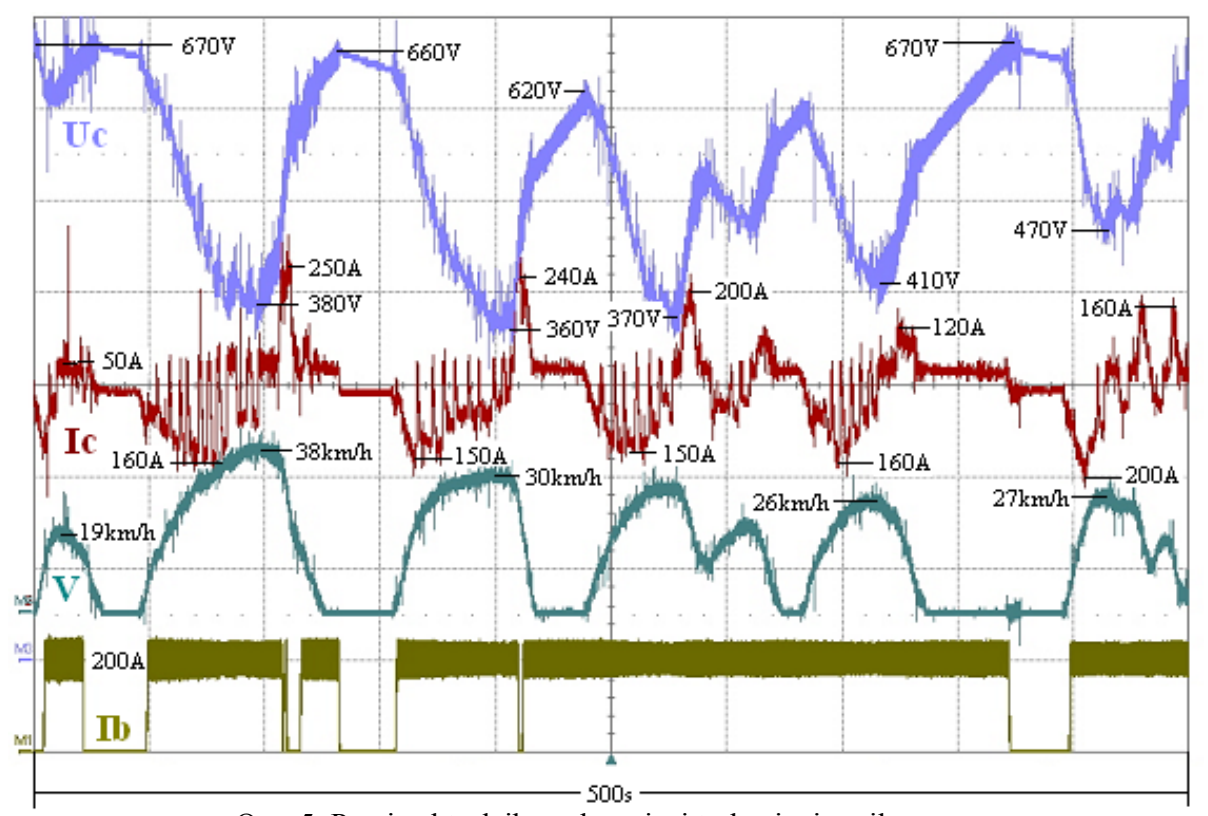

Osc. 5. Przejazd trolejbusu bez sieci trakcyjnej zasilanego $\mathrm{z}$ zasobnika kondensatorowego i baterii akumulatorów
> Zastosowany zasobnik kondensatorowy eliminuje problemy zatrzymania pojazdu pod izolatorem sekcyjnym, a także chwilowe przerwy w zasilaniu sieci.

$>$ Żywotność zasobnika kondensatorowego wynosi $\sim 10^{6}$ cykli tj. ok. 15 lat eksploatacji.

$>$ Żywotność zasobnika akumulatorowego przy rozładowaniu $25 \%$ to ok. 14000 cykli tj. ok. 2 lata eksploatacji.

$>$ Zastosowany przez Instytut Elektrotechniki układ hybrydowego zasilania pojazdu podlega prawnej ochronie zagwarantowanej przez Urząd Patentowy Rzeczpospolitej Polskiej. żywotności baterii akumulatorów to rozładowanie nie powinno przekraczać $30 \%$, tak więc na etapie projektowania powinna być znana długość odcinka bez sieci, jak również profil trasy.

Dla doładowania baterii do pojemności znamionowej długość trasy powinna wynosić $10 \div 12 \mathrm{~km}$ $(1,5 \div 2,0 \mathrm{~km}$ bez sieci $+8 \div 10 \mathrm{~km}$ przy zasilaniu $\mathrm{z}$ sieci trakcyjnej). Czas eksploatacji zastosowanej baterii przy rocznym przebiegu $60000 \mathrm{~km}$ wyniesie wg danych producenta $2,5 \div 3,5$ lat.

\section{Wnioski}

Badania ruchowe i eksploatacyjne trolejbusu z kondensatorowymi zasobnikami energii potwierdziły w pełni korzyści hybrydowego zasilania trolejbusu, odzysk energii wynosi ok. $30 \div 35 \%$.

$>$ Przejazd bez zasilania z sieci trakcyjnej, przy zastosowaniu samego zasobnika kondensatorowego, to ok. $400 \mathrm{~m}$, przy zachowaniu normalnych parametrów ruchowych.

$>$ Zastosowanie dodatkowej baterii akumulatorów umożliwia przejazd dłuższego odcinka, w zależności od pojemności i napięcia baterii. W naszym przypadku to ok. $1200 \div 2000 \mathrm{~m}$.

$>$ Przejęcie energii hamowania z V $=50 \mathrm{~km} / \mathrm{h}$ ok. $0,35 \mathrm{kWh}$.

$>$ Obcięcie szczytu oraz skrócenie czasu poboru z sieci maksymalnego prądu podczas rozruchu.

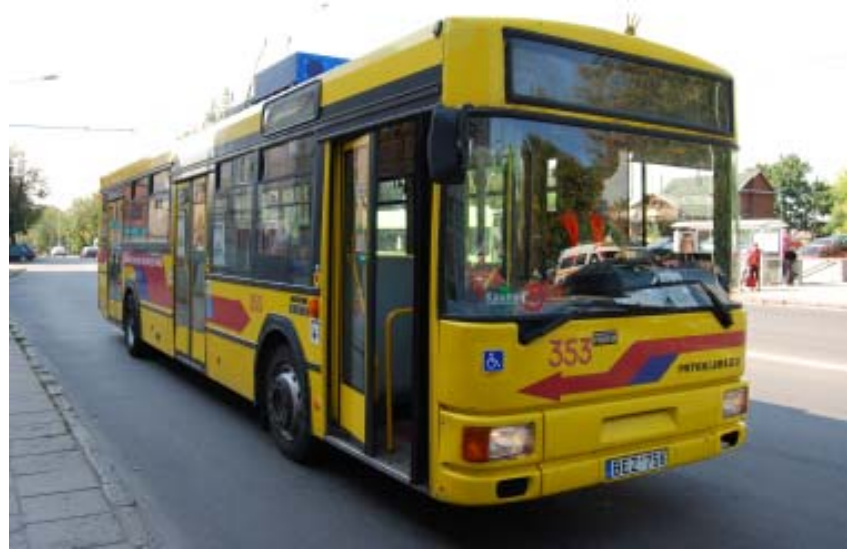

Trolejbus Jelcz M121 w Kownie

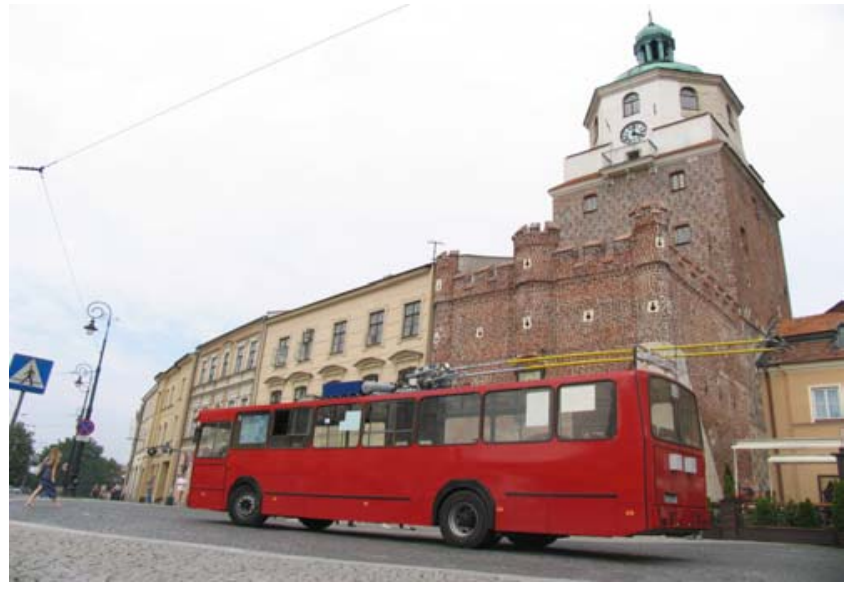

Trolejbus Jelcz PR110 w Lublinie 